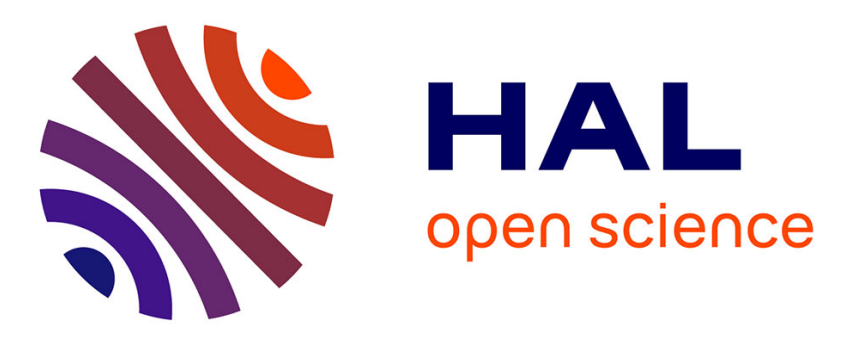

\title{
As-Grown InGaAsN Subcells for Multijunction Solar Cells by Molecular Beam Epitaxy
}

\author{
Maxime Levillayer, Alexandre Arnoult, Ines Massiot, Sophie Duzellier, \\ Thierry Nuns, Christophe Inguimbert, Corinne Aicardi, S. Parola, Helene \\ Carrere, Andrea Balocchi, et al.
}

\section{To cite this version:}

Maxime Levillayer, Alexandre Arnoult, Ines Massiot, Sophie Duzellier, Thierry Nuns, et al.. AsGrown InGaAsN Subcells for Multijunction Solar Cells by Molecular Beam Epitaxy. IEEE Journal of Photovoltaics, 2021, 11 (5), pp.1271-1277. 10.1109/JPHOTOV.2021.3093048 . hal-03330314

\section{HAL Id: hal-03330314 https://hal.laas.fr/hal-03330314}

Submitted on 31 Aug 2021

HAL is a multi-disciplinary open access archive for the deposit and dissemination of scientific research documents, whether they are published or not. The documents may come from teaching and research institutions in France or abroad, or from public or private research centers.
L'archive ouverte pluridisciplinaire HAL, est destinée au dépôt et à la diffusion de documents scientifiques de niveau recherche, publiés ou non, émanant des établissements d'enseignement et de recherche français ou étrangers, des laboratoires publics ou privés. 


\title{
As-grown InGaAsN subcells for multijunction solar cells by molecular beam epitaxy
}

\author{
M. Levillayer, A. Arnoult, I. Massiot, S. Duzellier, ,T. Nuns, C. Inguimbert, C. Aicardi, \\ S. Parola, H. Carrère, A. Balocchi, N. Vaissiere, J. Decobert, G. Almuneau, L. Artola
}

\begin{abstract}
In this article, we investigate the molecular beam epitaxy growth of unannealed $1.12 \mathrm{eV}$ InGaAsN solar cells. The impact of the growth temperature, the As/III ratio and the bismuth used as a surfactant is reported. An in-situ curvature measurement setup enables to monitor and ensure a constant $N$ incorporation during the InGaAsN growth. Ex-situ characterization results suggest that a high As/III ratio ensures good optoelectronic properties and that the growth temperature has a strong influence on the residual doping of the dilute nitride layer. Under $A M 0>870 \mathrm{~nm}$ and without anti-reflection coatings, our best InGaAsN solar cells exhibit $J_{s c}$ and $V_{o c}$ values of 7.94 $\mathrm{mA} / \mathrm{cm}^{2}$ and $0.375 \mathrm{~V}$ respectively. Considering no internal reflection and no grid shading, generation up to $12 \mathrm{~mA} / \mathrm{cm}^{2}$ in a multijunction solar cell can be expected, which is the highest value ever reported for as-grown InGaAsN cells to our knowledge.
\end{abstract}

Index Terms - Dilute nitride, InGaAsN, MBE, MJSC, $1 \mathrm{eV}$ cell

\section{INTRODUCTION}

$\mathrm{T}$ HE highest photovoltaic conversion efficiencies are achieved with multijunction solar cells (MJSC) based on III-V semiconductors [1]. However, most efficient MJSC remain at laboratory scale and require complex mechanical processing steps such as substrate removal [2] or wafer bonding [3]. These steps are difficult to implement at the industrial scale, which justifies the constant interest in monolithic growth. The need for high performance MJSC is currently driven by space applications, where the $\mathrm{GaInP} /(\mathrm{In}) \mathrm{GaAs} / \mathrm{Ge} 3$-junction cell lattice-matched to its Ge substrate is regarded as a standard.

Commercial 3-junction solar cells exhibit a $28-30 \%$ efficiency under AM0 [4], which could be enhanced through a more efficient conversion of the near infrared light. Theoretical calculations of the optimal bandgap combination highlighted the need to develop a $1 \mathrm{eV}$ subcell to improve spectral

This paper was submitted for review on April 07, 2021. A revised version was submitted on May 21, 2021 and on June 22, 2021.

We acknowledge the technical support from the LAAS-CNRS micro and nanotechnologies platform, a member of the French RENATECH network and the CNES for its financial support through R-S19/MT-9999-245 project. This work was also partly supported by the French program on «Investments for the future » managed by the National Agency for Research under contracts ANR10-LABX-22-01-SOLSTICE.

M. Levillayer, S. Duzellier, T. Nuns, C. Inguimbert, and L. Artola are with ONERA/DPHY, Université de Toulouse, 2 av. E. Belin, 31055 Toulouse, France (e-mail: maxime.levillayer@onera.fr). overlapping [5]. This subcell can replace Ge as the bottom cell in the current state-of-the-art 3-junction [6] or be integrated within a 4-junction solar cell [7]. Dilute nitrides have been studied as potential candidates for this application as nitrogen induces a high bandgap bowing coefficient for small $\mathrm{N}$ concentration [8], [9]. The main advantage of the InGaAsN quaternary alloys is that by tuning In and $\mathrm{N}$ compositions, lower bandgaps can be reached while remaining lattice-matched to GaAs or Ge substrates [10].

However, the growth of dilute nitride quaternary alloys was proven to be difficult because of the small size and the high electronegativity of the nitrogen anion. This leads to the formation of $\mathrm{N}$ induced defects detrimental to the optoelectronic properties and limits the solar cell performances [11], [12], [13]. The nitrogen plasma was also shown to introduce defects in the InGaAsN crystal because of reactive ion species [14].

These defects lead to low minority carrier diffusion length compared to other III-V semiconductors [15]. To mitigate this, $p-i-n$ and $n-i-p$ structures were developed to collect photocarriers through both drift and diffusion processes. For such a collection regime to be possible, the background carrier concentration (BGCC) needs to be low enough to ensure a wide space charge region. Achieving low residual doping has proven to be quite challenging and appears to be very sensitive to the growth conditions [16], [17].

For molecular beam epitaxy (MBE), Aho et al. [18] showed the necessity of growing InGaAsN within a $420-480^{\circ} \mathrm{C}$ temperature window (with $A s / I I I=10$ ) to ensure a high-quality two-dimensional growth. On the other hand, Ptak et al. [17] reported that the lowest BGCC could be obtained for growth temperature ranging from 500 to $540^{\circ} \mathrm{C}$.

The other important growth parameter is the ratio between $\mathrm{V}$ and III elements approximated here as the As/III beam equivalent pressure (BEP) ratio. The arsenic overpressure is

A. Arnoult, I. Massiot and G. Almuneau are with LAAS-CNRS, 7 av. du Colonel Roche, 31400 Toulouse, France

C. Aicardi is with CNES, 18 av. E. Belin, 31400 Toulouse, France

S. Parola is with IES, Université de Montpellier, CNRS, 860 Rue de St Priest, 34095, Montpellier, France.

H. Carrère and A. Balocchi are with LPCNO, 135 av. de Rangueil, 31077 Toulouse, France

N. Vaissière and J. Decobert are with III-V Lab, 1 av. Augustin Fresnel, 91767, Palaiseau, France 
reported to have a strong impact on the optical and electrical properties of InGaAsN, as it affects the $\mathrm{N}$ incorporation rate and the N nearest-neighbour configuration [13], [19].

Regarding $1 \mathrm{eV}$ subcells, today's main challenge is to reach short circuit current density $\left(J_{s c}\right)$ values large enough to satisfy the current matching condition within the MJSC. $J_{s c}$ values higher than $15 \mathrm{~mA} / \mathrm{cm}^{2}$ have already been reported for $\mathrm{AM} 0>870 \mathrm{~nm}$ [6], [13] and AM1.5>830 nm [20] irradiance. However, the InGaAsN solar cells reported in those studies require annealing after the $\mathrm{MBE}$ growth, which can be a problematic step to implement during MJSC monolithic growth. Indeed, degradation of tunnel junctions [21], [22], [23], dopant out-diffusion [24] and InGaAsN bandgap blueshift [25] are multiple issues that can occur after thermal annealing.

Our approach consists in optimizing the MBE growth of $1 \mathrm{eV}$ InGaAsN alloys that do not require a post-growth rapid thermal annealing (RTA). A homemade in-situ curvature measurement setup [26] was used to monitor the $\mathrm{N}$ composition and its possible variation across thick layers. The impact of different growth parameters such as the substrate temperature and the arsenic overpressure represented by the $A s / I I I$ ratio, was assessed. The influence of bismuth as a growth surfactant was also investigated, as it was reported to smooth the surface during growth [27], [28] and enhance nitrogen incorporation [27], [29]. Finally, the InGaAsN cells were characterized using various techniques such as internal quantum efficiency (IQE), photoluminescence (PL), electrochemical capacitance voltage measurement (ECV) and $J-V$ under dark and AM0>870 nm illumination conditions.

\section{EXPERIMENTAL PROCEDURE}

\section{A. MBE growth details}

InGaAsN $p-i-n$ solar cells were grown by MBE on 4-inch $n$ doped GaAs (001) substrates in a Riber MBE412 solid source MBE system equipped with a RF valved plasma nitrogen source. The outlet of this source includes a metallic plate that eliminates electrons and ion species [30], [31]. Uncracked arsenic tetramers $\mathrm{As}_{4}$ were provided through a valve cracker source and carbon was introduced with a $\mathrm{CBr}_{4}$ injector. The substrate temperature was monitored with a thermocouple and the BEP of the different elements were measured with an ion gauge. The devices consist of a $p-i-n \mathrm{GaAs} / \mathrm{InGaAsN} / \mathrm{GaAs}$ structure including a n- $\mathrm{Al}_{0.4} \mathrm{Ga}_{0.6} \mathrm{As}$ back surface field (BSF), a $\mathrm{p}-\mathrm{Al}_{0.4} \mathrm{Ga}_{0.6} \mathrm{As}$ window and a $\mathrm{p}+\mathrm{GaAs}$ cap layer (as depicted on Fig. 1).

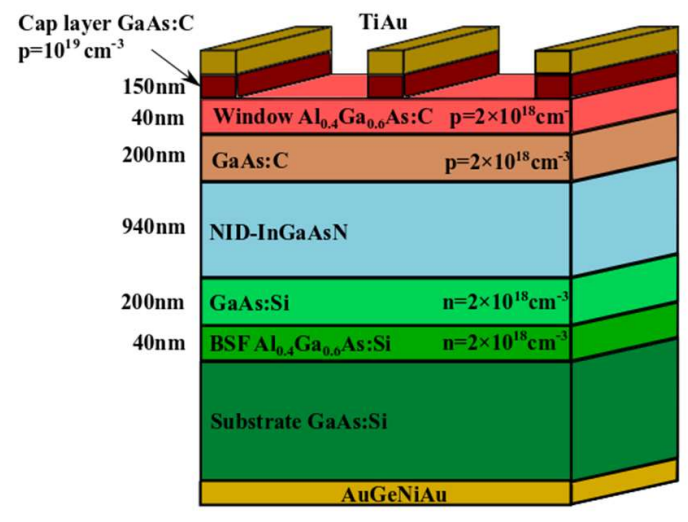

Fig. 1. Structure of the InGaAsN cells with targeted values for doping concentration, alloy composition and thickness.

InGaAsN growth conditions were varied from one sample to the next (see TABLE I. ) while identical conditions were used for the rest of the structure. The effective substrate temperature was inferred from the measured temperature $T_{0}$ at which the $(2 \times 4) \rightarrow c(4 \times 4)$ GaAs surface reconstruction transition took place. This surface reconstruction was observed with reflection high-energy electron diffraction (RHEED) under an As BEP equal to $1.2 \times 10^{-5}$ Torr and was reported to occur at $525^{\circ} \mathrm{C}$ by Labella et al. [32]. The indium composition was calibrated based on the PL signal of InGaAs quantum wells. The InGaAsN layers were grown with a $0.3 \mu \mathrm{m} / \mathrm{h}$ growth rate. The nitrogen plasma power was set at $450 \mathrm{~W}$ with a $0.3 \mathrm{sccm} \mathrm{N}_{2}$ flow. For sample A, the Bi flux was set at $2.6 \times 10^{-8}$ Torr.

The nitrogen incorporation was controlled thanks to a highsensitivity in-situ curvature measurement setup developed inhouse [26], allowing us to tune in real-time the $\mathrm{N}$ flow and preserve an adequate $\mathrm{In} / \mathrm{N}$ ratio to remain lattice-matched to $\mathrm{GaAs}$. The In and $\mathrm{N}$ compositions of the InGaAsN active layer deduced from the alloy bandgap $(1.12 \mathrm{eV})$ are respectively $4.5 \%$ and $1.6 \%$ [33], [34], corresponding to the lattice-matched condition at growth temperature. The lattice-matching of the epilayers at room temperature was then confirmed by X-ray diffraction post-growth analysis showing single peak with a full width at half maximum below 34 arcseconds.

TABLE I. INGAASN GROWTH CONDITIONS

\begin{tabular}{|c|c|c|c|}
\hline Sample & Surfactant & Growth Temperature & As/III ratio \\
\hline $\mathrm{A}$ & $\mathrm{Bi}$ & $\mathrm{T}_{0}-60^{\circ} \mathrm{C}=465^{\circ} \mathrm{C}$ & 12 \\
\hline $\mathrm{B}$ & $\varnothing$ & $\mathrm{T}_{0}-60^{\circ} \mathrm{C}=465^{\circ} \mathrm{C}$ & 12 \\
\hline $\mathrm{C}$ & $\varnothing$ & $\mathrm{T}_{0}-80^{\circ} \mathrm{C}=445^{\circ} \mathrm{C}$ & 10 \\
\hline $\mathrm{D}$ & $\varnothing$ & $\mathrm{T}_{0}-40^{\circ} \mathrm{C}=485^{\circ} \mathrm{C}$ & 10 \\
\hline
\end{tabular}


Fig. 2a) shows the evolution of the stress $\times$ thickness product $\sigma_{e} h_{e}$ during the growth of the InGaAsN epilayer. This product was calculated from the epilayer curvature (1/R) using Stoney's equation, which can be expressed as:

$$
\sigma_{e} h_{e}=\frac{M_{s} h_{s}^{2}}{6 R}
$$

where $M_{s}$ and $h_{s}$ are the biaxial modulus and the thickness of the GaAs substrate. The stress of the epilayers was then calculated from the slopes of this graph and the strain $\varepsilon_{/ /}$was obtained using Hooke's law:

$$
\sigma_{e}=\varepsilon_{/ /} \times \frac{\left(C_{11}+2 C_{12}\right)\left(C_{11}-C_{12}\right)}{C_{11}}
$$

where $C_{11}$ and $C_{12}$ are the elastic constants of the epilayer approximated as the values known for $\operatorname{In}_{0.05} \mathrm{Ga}_{0.95} \mathrm{As}$ [35]. The lattice parameter of the InGaAsN epilayer was then deduced from the strain value and the nitrogen content $x$ was calculated using a double Vegard law [36]:

$$
\begin{aligned}
& a_{I n_{0.045} G_{a A s N_{x}}}=(0.955-x) \times a_{G a A s} \\
& +x \times a_{G a N}+0.045 \times a_{I n A s}
\end{aligned}
$$

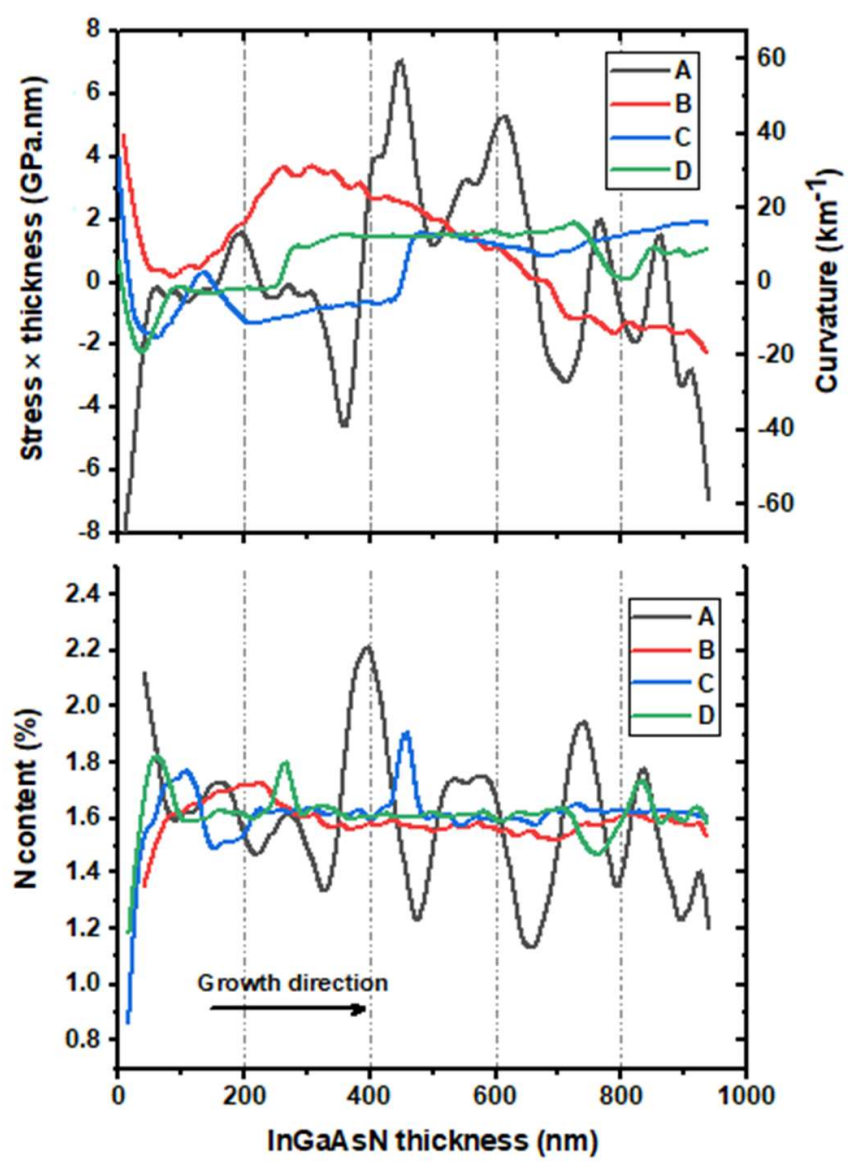

Fig. 2. a) Stress $\times$ thickness evolution during InGaAsN growth b) Nitrogen composition profiles along the InGaAsN layer deduced from a).
Fig. 2b) depicts the $\mathrm{N}$ content profile across the dilute nitride layer. As evidenced by these profiles, the $\mathrm{N}$ composition is very stable over the InGaAsN layers except for sample A for which more important fluctuations up to $\pm 1 \%$ are observed. This latter fluctuation is due to a non-optimized adjustment procedure for the aperture of $\mathrm{N}$ valve cell during the growth of sample A.

\section{B. Device processing}

The epitaxial structures were then processed into $0.25 \mathrm{~cm}^{2}$ for EQE measurements and $1 \mathrm{~cm}^{2}$ solar cells for $J-V$ characterizations. AuGeNi/Au metallization was carried out on the backside by sputtering and $\mathrm{Ti} / \mathrm{Au}$ contacts were deposited on the frontside by e-beam evaporation through patterning photolithography and lift-off steps. A surface deoxidation with $\mathrm{HCl}$ was performed before both metal depositions. Wafers were then annealed at $350^{\circ} \mathrm{C}$ for $90 \mathrm{~s}$ under $\mathrm{H}_{2} / \mathrm{N}_{2}$ atmosphere in order to achieve good ohmic contacts. A second photolithography step was carried out and mesa wet etching was performed using $\mathrm{H}_{3} \mathrm{PO}_{4} / \mathrm{H}_{2} \mathrm{O}_{2}$. The $\mathrm{GaAs}$ cap layer was selectively removed using $\mathrm{C}_{6} \mathrm{H}_{8} \mathrm{O}_{7} / \mathrm{H}_{2} \mathrm{O}_{2}$. No anti-reflection coatings (ARC) was deposited on the frontside. Solar cells with $5 \%$ grid shading factor were finally cleaved. The final cell structure is shown in Fig. 1. No high temperature rapid thermal annealing was performed during or after the MBE growth on the epiwafers.

\section{RESULTS AND DISCUSSION}

\section{A. Material characterization}

The samples were characterized by photoluminescence at $10 \mathrm{~K}$ using a Ti-Sa pulsed $950 \mathrm{~nm}$ laser excitation source. As depicted in Fig. 3, the PL spectrum shape is similar for all samples whereas the intensity of the band-to-band recombination peak is found to vary greatly from one sample to the next. Especially, it is found that samples A and B grown with a $A s / I I I$ ratio equal to 12 give a higher PL signal than samples $\mathrm{C}$ and $\mathrm{D}$ grown with $A s / I I I=10$. This degradation of the PL intensity when reducing the arsenic overpressure during growth is attributed to the creation of point-defects enhancing Shockley-Read-Hall (SRH) recombination. This corroborates measurements reported on as-grown InGaAsN quantum wells [19]. However, it does not concur with results reported for $0.93 \mathrm{eV} \operatorname{In}_{0.1} \mathrm{GaAsN}_{0.03}$ solar cells [13], probably because the optimization of these cells was considered after a thermal annealing step. Additionally, the nitrogen content of these cells is approximately twice higher than it is in our cells, which is likely to shift the optimal growth conditions. Furthermore, we can see the effect of the nitrogen content dispersion on the broad high energy peak exhibited by sample A. Indeed, Fig. 2b) shows that the $\mathrm{N}$ content in this sample is not homogeneous across the absorber layer. Assuming the InGaAsN absorption coefficient is equivalent to the GaAs one red-shifted by $240 \mathrm{~nm}$, the absorption depth of the laser is approximately equal to $440 \mathrm{~nm}$. 


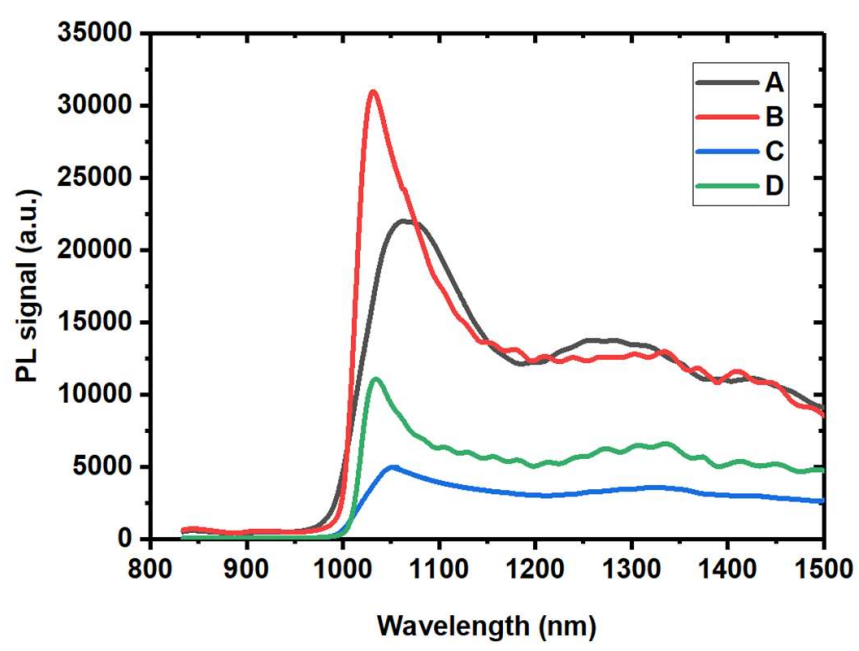

Fig. 3. PL spectra of InGaAsN solar cells measured at $10 \mathrm{~K}$. The broad peak appearing at higher wavelength originates from the $\mathrm{n}^{+}$-doped $\mathrm{GaAs}$ substrate.

Consequently, both the photogeneration and the radiative recombination of carriers can take place at different depths (and thus for different bandgap values), which explains the broader peak for sample A. Indeed, the bandgap energy of $\mathrm{In}_{0.045} \mathrm{GaAsN}_{\mathrm{x}}$ is calculated to be $1.15 \mathrm{eV}(\lambda=1075 \mathrm{~nm})$ for $\mathrm{x}=1.2 \%$ and $1.07 \mathrm{eV}(\lambda=1157 \mathrm{~nm})$ for $\mathrm{x}=2 \%$. Moreover, sample $\mathrm{A}$ is found to exhibit a lower PL signal than sample B, these two samples having been grown under the same growth temperature and $A s / I I I$ ratio, but respectively with and without the bismuth surfactant. This difference can be explained by the lower PL emission of region with high nitrogen content in sample A. It could also be ascribed to the creation of nonradiative recombination centers caused by the presence of $\mathrm{Bi}$ during growth. However, it seems unlikely that those defects arise from the presence of $\mathrm{Bi}$ atoms after growth, as they virtually do not incorporate under the growth conditions used here [27].

ECV measurements were performed on the samples to evaluate the BGCC in the InGaAsN layer (Fig. 4). The substrate doping concentrations measured by ECV were identical for every sample and in agreement with the substrate specifications $\left(N_{d}=2 \times 10^{18} \mathrm{~cm}^{-3}\right)$. The doping tail around the InGaAsN/GaAs interface is likely to arise from inhomogeneous etching depth, exposing at the surface simultaneously the NID-InGaAsN and n-GaAs layers. Indeed, profilometry measurement of the etching base after ECV showed a depth variation as high as $90 \mathrm{~nm}$, which is of the same order of magnitude as the doping tail extent.

The InGaAsN layers in samples A, B, and C exhibited a ntype BGCC with values ranging from $4 \times 10^{15}$ to $3 \times 10^{16} \mathrm{~cm}^{-3}$. The doping of interest for our $p-i-n$ structure is the value found between 0 and $0.5 \mu \mathrm{m}$ as it defines the extent of the space charge region (SCR) between the $\mathrm{p}-\mathrm{GaAs}$ emitter and the $\mathrm{n}^{-}$ InGaAsN absorber. $N_{d}$ values for sample $\mathrm{A}$ and $\mathrm{B}$ could not be properly measured and we considered a plateau region from 0 to $0.3 \mu \mathrm{m}$ as is the case for sample $\mathrm{C}$.

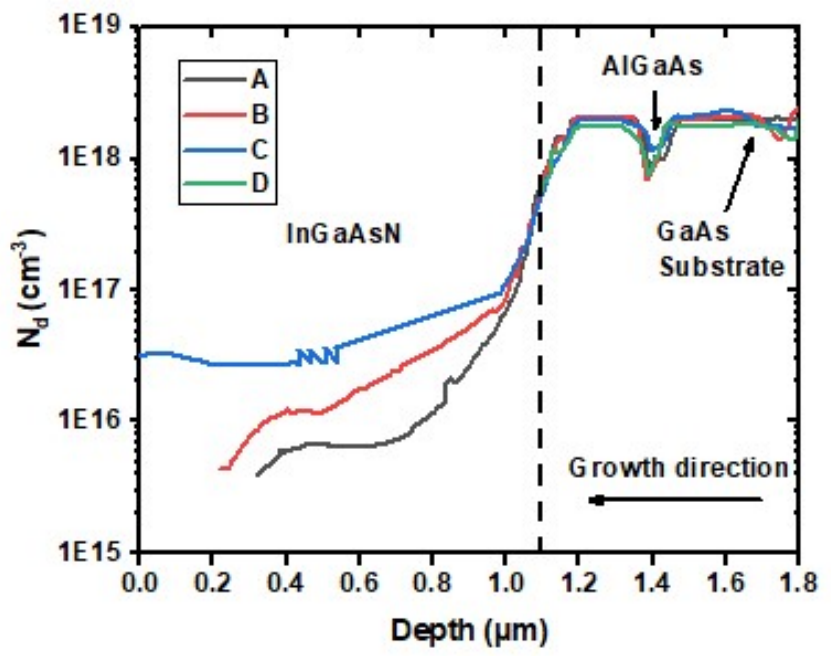

Fig. 4. Doping concentration profile of InGaAsN solar cells.

The residual doping of sample $\mathrm{D}$ was found to be below the detection limit and is estimated to be less than $4 \times 10^{15} \mathrm{~cm}^{-3}$ which is in the low range of the reported values for InGaAsN. In Fig. 4, the ECV profile of sample D appears only for the top layers, showing similar doping values for $\mathrm{GaAs}$ and $\mathrm{AlGaAs}$ as in other samples.

The extension of the SCR can be calculated assuming that the dielectric permittivity of the dilute nitride layer is the same as GaAs and considering a built-in voltage of $0.5 \mathrm{~V}$. The SCR width is estimated to range from $150 \mathrm{~nm}$ for sample $\mathrm{C}$, to more than $420 \mathrm{~nm}$ for sample D. These depletion widths are very similar to results reported by Jackrel et al. [37], but shorter than what is reported for BGCC lower than $5 \times 10^{14} \mathrm{~cm}^{-3}$ [38], [39].

The three InGaAsN doping profiles of Fig. 4 show that the BGCC decreases when the growth temperature of the dilute nitride is increased. This is due to the intrinsic nature of the residual doping, which arises from donor defects rather than from impurities. As with the $A s / I I I$ ratio, changing the growth temperature is thought to play a major role in the formation of growth defects. Our results are in good agreement with the values reported by Ptak et al. for as-grown InGaAsN [17].

\section{B. In GaAsN solar cells characterization}

We measured the external quantum efficiency and the reflectance of the solar cells to evaluate their IQE shown in Fig. 5. Overall, samples $\mathrm{A}$ and $\mathrm{B}$, grown with an $A s / I I I=12$ ratio, exhibit better quantum efficiency than samples $\mathrm{C}$ and $\mathrm{D}$. In addition, we observe that the nitrogen composition variations do not affect significantly the InGaAsN optoelectronics properties as sample A and B have a very similar spectral response and cut-off wavelength. Interestingly, the IQE spectra of the 4 samples correlate well with their relative PL intensity. This suggests that the collection efficiency is limited by the SRH recombination rate and by the minority carrier diffusion length. In order to study these spectra further, we can observe the IQE values at wavelengths longer than $870 \mathrm{~nm}$, which is the cut-off wavelength of GaAs. The collection efficiency in this spectral window can only originate from absorption within the nitride layer whereas at shorter wavelengths, it arises from 
absorption in both the GaAs emitter and the InGaAsN absorber. Sample D exhibits an IQE almost as high as samples A and B for $\lambda>870 \mathrm{~nm}$, which contrasts with PL observation and thus cannot be explained by using the diffusion collection regime alone. Instead, drift collection or field-aided-collection needs to be accounted for, as the electric field helps to sweep the carriers in the SCR. The contribution of the drift collection explains the relatively high quantum efficiency of sample D which has the lowest BGCC.

On the other hand, we can see that sample $\mathrm{C}$ - which was grown at a lower temperature and has a higher BGCC than sample D - does not benefit much from field-aided collection. The difference between samples $\mathrm{C}$ and $\mathrm{D}$ can be observed at $\approx 650 \mathrm{~nm}$ as the IQE of $\mathrm{C}$ starts to decrease whilst it increases for $\mathrm{D}$.

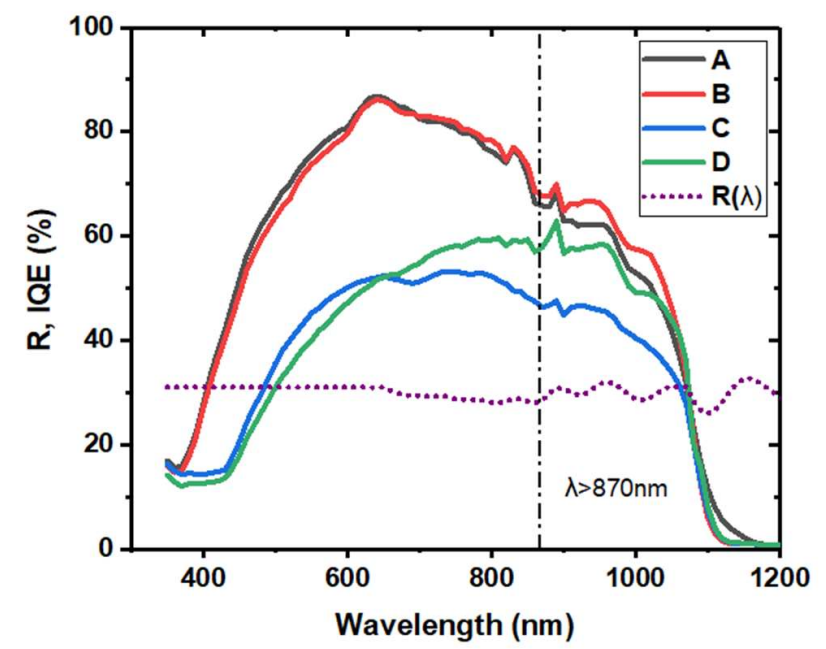

Fig. 5. Internal quantum efficiency and reflectance spectra of $0.25 \mathrm{~cm}^{2}$ InGaAsN solar cells.

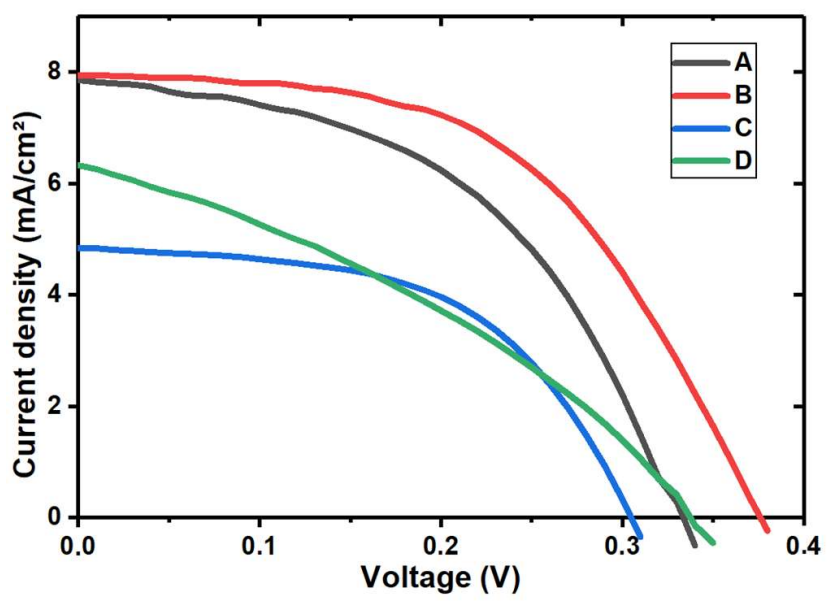

Fig. 6. $J-V$ characteristics of $1 \mathrm{~cm}^{2}$ InGaAsN solar cells measured at $25^{\circ} \mathrm{C}$ under $\mathrm{AM} 0>870 \mathrm{~nm}$ light.
The impact of the growth conditions can also be assessed through the light $J-V$ measurements that are presented in Fig. 6 . The $J-V$ characteristics were measured with an Oriel solar simulator equipped with a Xenon lamp and a AM0 filter, calibrated with a reference 3-junction cell and a reference GaAs solar cell. A Newport long-pass filter $(\lambda>870 \mathrm{~nm})$ was placed in the optical path to reproduce the absorption of upper subcells in MJSC. The short-circuit current density $J_{s c}$, the open-circuit voltage $V_{o c}$ and the fill factor $F F$ of the four cells are summarized in TABLE II.

Solar cells A and B grown at $465^{\circ} \mathrm{C}$ with a $A s / I I I=12$ exhibit better $J-V$ characteristics than the other cells, which is in agreement with PL and IQE observations. Sample B was able to generate $7.94 \mathrm{~mA} / \mathrm{cm}^{2}$. Accounting for a $5 \%$ grid shading and a reflectance measured around $30 \%$ in the $870-1300 \mathrm{~nm}$ spectral range, and considering no internal reflection within the MJSC, this solar cell could photogenerate up to $12 \mathrm{~mA} / \mathrm{cm}^{2}$ in operating conditions. This value exceeds the highest photocurrent reported for unannealed (as-grown) InGaAsN solar cells [17], [40].

The open-circuit voltage of sample A was found to be lower than for sample $B$, which concurs with PL results. This indicates a higher carrier recombination rate in sample A that can either be attributed to defects introduced by bismuth or to higher $\mathrm{N}$ content fluctuation. Overall, the 4 solar cells exhibited large bandgap $-V_{o c}$ deficit $\left(W_{o c}\right)$ compared to values reported in the literature [13], [41].

The relatively low value of the fill factors is imputed to the drift collection in the depletion region. As the voltage is increased, the width of the SCR decreases which reduces the field-aided collection. It can also be noticed that this phenomenon is more pronounced for samples with low BGCC. Fig. 7 shows the dark $J-V$ characteristics of the solar cells. The series and shunt resistances were calculated from these characteristics and are summarized in TABLE II. The obtained values confirm that the very low $F F$ of sample D cannot be attributed to shunt, and rather arises from the variation of the SCR with voltage. The relatively high series resistances are thought to originate from the $\mathrm{n}^{+} \mathrm{GaAs} / \mathrm{AuGeNi}$ contact on the rear side of the cells. Lowering this contact resistance could bring the fill factor to $60-70 \%$, as reported for state of the art cells [37], [41].

TABLE II. CHARACTERISTICS OF INGAASN SOLAR CELLS

\begin{tabular}{|c|c|c|c|c|c|c|c|}
\hline & $\begin{array}{c}\mathbf{J}_{\text {sc }} \\
\left(\mathbf{m A} / \mathbf{c m}^{\mathbf{2}}\right)\end{array}$ & $\begin{array}{c}\mathbf{V}_{\text {oc }} \\
(\mathbf{V})\end{array}$ & $\begin{array}{c}\mathbf{F F} \\
(\mathbf{\%})\end{array}$ & $\begin{array}{c}\mathbf{V}_{\mathbf{m p}} \\
(\mathbf{V})\end{array}$ & $\begin{array}{c}\mathbf{n} \\
\mathbf{a t} \mathbf{V}_{\mathbf{m p}}\end{array}$ & $\begin{array}{c}\mathbf{R}_{\text {series }} \\
\left(\mathbf{\Omega} / \mathbf{c m}^{\mathbf{2}}\right)\end{array}$ & $\begin{array}{c}\mathbf{R}_{\text {shunt }} \\
\left(\mathbf{\Omega} / \mathbf{c m}^{\mathbf{2}} \mathbf{)}\right.\end{array}$ \\
\hline A & 7.86 & 0.335 & 48.3 & 0.22 & 1.63 & 10.9 & 22500 \\
\hline B & 7.94 & 0.375 & 52.6 & 0.25 & 1.66 & 22.1 & 93400 \\
\hline C & 4.84 & 0.305 & 54.1 & 0.22 & 1.57 & 15.0 & 29800 \\
\hline D & 6.33 & 0.34 & 34.6 & 0.20 & 1.97 & 24.5 & 13100 \\
\hline
\end{tabular}




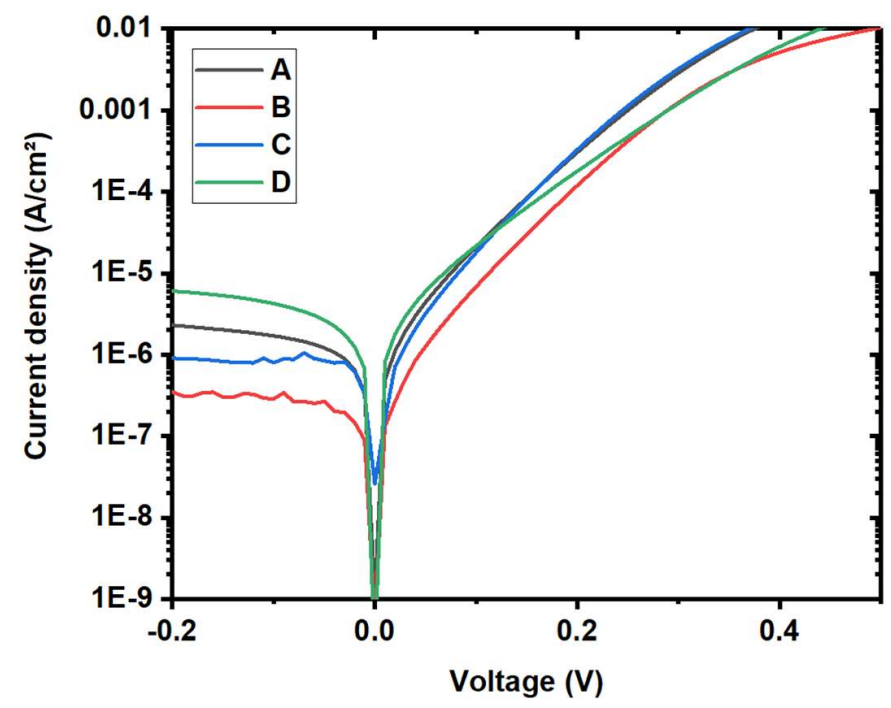

Fig. 7. Dark $J-V$ characteristics of the $1 \mathrm{~cm}^{2}$ InGaAsN solar cells measured at $25^{\circ} \mathrm{C}$.

The ideality factors of the cells at maximum power voltage $\left(V_{m p}\right)$ were extracted from the slope of the dark $J-V$ curves, and can be found in TABLE II. We can see that $n$ ranges from around 1.6 for sample A, B and C to almost 2 for sample D. An ideality factor equal to 2 implies that the recombination rate depends on both carrier types, which means that most of the recombination takes place within the depletion region. This is consistent with what has seen observed before as the high ideality factor of sample D arises from its large SCR.

Through all of these characterizations, it appears that the As/III ratio is a crucial growth parameter which strongly affects the photovoltaic performances of the solar cells. The decrease in $J_{s c}, V_{o c}, \mathrm{IQE}$ and PL when the $A s / I I I$ is lowered to 10 does not agree with the results reported by Polojärvi et al [13]. However, a global study of the literature reveals that the growth optimization of dilute nitrides is highly dependent on their nitrogen content and on the annealing conditions. In addition, the growth temperature was found to greatly impact the residual doping of the dilute nitride layer. Setting the growth temperature higher than $485^{\circ} \mathrm{C}$ could result in a very low n-type doping or even a p-type doping as this transition was reported to occur between 500 to $540^{\circ} \mathrm{C}$ [17]. However, for such a high growth temperature, the $A s / I I I$ ratio needs to be optimized to ensure that the low BGCC does not come at the price of a high recombination rate.

Under the investigated growth conditions, the bismuth surfactant effect was not found to be conclusive. The comparison between samples A and B (respectively with and without $\mathrm{Bi}$ ) is biased as sample A exhibits larger fluctuation of nitrogen concentration. It is also possible that the Bi flux was too low in order to promote the surfactant effect [29].

\section{CONCLUSIONS AND PERSPECTIVES}

In this work, investigations have been conducted on the growth of as-grown dilute nitride solar cells assessing the respective effects of the $A s / I I I$ ratio and the growth temperature.
Unnanealed $1.12 \mathrm{eV} \mathrm{InGaAsN}$ solar cells able to generate $\approx 8 \mathrm{~mA} / \mathrm{cm}^{2}$ under AM0> $870 \mathrm{~nm}$ without ARC $\left(12 \mathrm{~mA} / \mathrm{cm}^{2}\right.$ estimated in integration conditions) were demonstrated. The $A s / I I I$ ratio was found to be a critical parameter in minimizing the density of non-radiative recombination centers and should be kept higher than 10 to ensure good photovoltaic performances. In addition, the growth temperature was reported to have a large impact on the BGCC which arises from intrinsic doping. Growing InGaAsN at a high temperature leads to a low residual doping and a wide depletion region.

Based on both this study and the literature, it can be concluded that the optimal growth parameters are highly dependent on the targeted nitrogen content and on the annealing conditions. Identifying the application and the specific needs for the dilute nitride subcell (bandgap energy, monolithic growth process, nature of the other junctions) is necessary before conducting thorough optimization. To integrate an asgrown dilute nitride cell within a $\mathrm{GaInP} / \mathrm{GaAs} / \mathrm{InGaAsN} / \mathrm{Ge}$ monolithic structure, the growth of InGaAsN with a bandgap equal to $1.0 \mathrm{eV}$ should be optimized. Additional requirements, such as radiation hardness, must be fulfilled if these fourjunction cells are to be used for space applications.

\section{ACKNOWLEDGMENT}

The authors acknowledge F. Pichot from CTM University of Montpellier for AuGeNi/Au metallization.

\section{REFERENCES}

[1] M. A. Green, E. D. Dunlop, J. Hohl-Ebinger, M. Yoshita, N. Kopidakis and X. Hao, "Solar cell efficiency tables (version 56)," Prog in Photov., vol.28, pp. 629-638, Jun. 2020.

[2] J. F. Geisz, R. M. France, K. L. Schulte, M. A. Steiner, A. G. Norman, H. L. Guthrey, M. R. Young, T. Song and T. Moriarty, "Six-junction III-V solar cells with $47.1 \%$ conversion efficiency under 143 Suns concentration," Nat. Energy, vol. 5, no. 4, pp. 326-335, Apr. 2020

[3] F. Dimroth et al., "Four-junction wafer-bonded concentrator solar cells," IEEE J. Photovoltaics, vol. 6, no. 1, pp. 343-349, Jan. 2016.

[4] A. W. Bett, S. P. Philipps, S. Essig, S. Heckelmann, R. Kellenbenz, V. Klinger, M. Niemeyer, D. Lackner and F. Dimroth, "Overview about technology perspectives for high efficiency solar cells for space and terrestrial applications," 28th EU PVSEC, 2013

[5] S. R. Kurtz, D. Myers and J. M. Olson "Projected performance of threeand four-junction devices using GaAs and GaInP," Proceedings of the 26th IEEE PVSC, p. 875, 1997

[6] A. Tukiainen et al. "High-efficiency GaInP/GaAs/GaInNAs solar cells grown by combined MBE-MOCVD technique," Prog in Photov., vol. 24, pp. 914-919, May 2016

[7] A. Aho et al. "Lattice-matched four-junction tandem solar cell including two dilute nitride bottom junctions," Prog in Photov., vol. 27, pp. 299305,2019

[8] M. Weyers, M. Sato and H. Ando, "Red shift of photoluminescence and absorption in dilute GaAsN alloy layers," Jpn. J. Appl. Phys., vol. 31, pp. 853-855, Jul. 1992

[9] S. H. Wei and A. Zunger, "Giant and composition-dependent optical bowing coefficient in GaAsN alloys," Phys. Rev. Lett., vol. 76, no. 4, pp. 664-667, Jan. 1996.

[10] M. Kondow, K. Uomi, A. Niwa, T. Kitatani, S. Watahiki and Y. Yazawa, "GaInNAs: A novel material for long-wavelength-range laser diodes with excellent high-temperature performance," Jpn. J. Appl. Phys., vol.35, pp. 1273-1275, Feb. 1996

[11] R. Kaplar, D. Kwon, S. A. Ringel, A. A. Allerman, S. R. Kurtz, E. D. Jones and R. M. Sieg, "Deep levels in p- and n-type InGaAsN for high- 
efficiency multi-junction III-V solar cells," Sol. Energy Mater. Sol. Cells, vol. 69 , pp. 85-91, 2001

[12] A. Khan, S. R. Kurtz, S. Prasad, S. W. Johnston and J. Gou "Correlation of nitrogen related traps in InGaAsN with solar cell properties," Appl. Phys. Lett., vol. 90, 2007

[13] V. Polojarvi, A. Aho, A. Tukiainen, M. Raappana, T. Aho, A. Schramm and M. Guina "Influence of As/group-III flux ratio on defects formation and photovoltaic performance of GaInNAs solar cells," Sol. Energy Mater. Sol. Cells, vol. 149, pp. 213-220, 2016

[14] S.R. Bank, M.A. Wistey, H.B. Yuen, L.L. Goddard, H. Bae and J.S. Harris "Molecular-beam epitaxy of low threshold cw GaInNAsSb lasers at 1.5 um," J. Vac. Sci. Technol. B, vol.23(3), pp.1337-1340, June 2005

[15] S. R. Kurtz, A. A. Allerman, C.H. Seager, R.M. Sieg and E.D. Jones "Minority carrier diffusion, defects, and localization in InGaAsN, with 2\% nitrogen," Appl. Phys. Lett., vol.7(3), pp. 400-402, Jul. 2000

[16] F. Langer, S. Perl, S. Höfling and M. Kamp, "p- to n-type conductivity transition in $1.0 \mathrm{eV}$ GaInNAs solar cells controlled by the V/III ratio," Appl. Phys. Lett., vol.106, 063905, 2015

[17] A. J. Ptak, D. J. Friedman and S. Kurtz "Effects of temperature, nitrogen ions, and antimony on wide depletion width GaInNAs," J. Vac. Sci. Technol. B, vol.25(3), pp. 955-959, 2007

[18] A. Aho, V. Polojarvi, V.M. Korpijarvi, J. Salmi, A. Tukiainen, P. Laukkanen and M. Guina, "Composition dependent growth dynamics in molecular beam epitaxy of GaInNAs solar cells," Sol. Energy Mater. Sol. Cells, vol. 124, pp. 150-158, 2014

[19] E. M. Pavalescu, T. Hakkarainen, V. D. S. Dhaka, N. V. Tkachenko, T. Jouhti, H. Lemmetyinen and M. Pessa, "Influence of arsenic pressure on photoluminescence and structural properties of GaInNAs/GaAs quantum wells grown by molecular beam epitaxy," J. Cryst. Growth, vol. 281, pp. 249-254, 2005

[20] M. M. Wilkins et al. "Design of thin $\operatorname{InGaAsN}(\mathrm{Sb})$ n-i-p junctions for use in four-junction concentrating photovoltaic devices," J. Photonics Energy, vol. 7(2), 022502, Apr. 2017

[21] P. Colter, B. Hagar and S. Bedair "Tunnel Junctions for III-V Multijunction Solar Cells Review," Crystals, vol.8, 445, 2018

[22] I. Rey-Stolle et al. "On the Thermal Degradation of Tunnel Diodes in Multijunction Solar Cells," Proceeding of the 13th International Conference on Concentrator Photovoltaic Systems, 040005-1, 2017

[23] W. Dawidowski, B. Ściana, I. Zborowska-Lidnert, M. Mikolášek, J. Kováč and M. Tłaczała "Tunnel Junction limited performance of InGaAsN/GaAs tandem solar cell," Solar Energy, vol.214, pp. 632-641, 2021

[24] I. Garcia et al. "Degradation of subcells and tunnel junctions during growth of $\mathrm{GaInP} / \mathrm{Ga}$ (In)As/GaNAsSb/Ge 4-junction solar cells," Prog in Photov., vol.25, pp. 887-895, 2017

[25] K. Volz, D. Lackner, I. Nemeth, B. Kunert, W. Stolz, C. Baur, F. Dimroth and A. W. Bett, "Optimization of annealing conditions of (GaIn)(NAs) for solar cell applications," J. Cryst. Growth, vol. 310, pp. 2222-2228, 2008.

[26] A. Arnoult and J. Colin "Magnification inferred curvature for real-time curvature monitoring," Sci Rep, 11(1), pp. 1-11, April 2021

[27] S. Tixier, M. Adamcyk, E. C. Young, J. H. Schmid and T. Tiedje, "Surfactant enhanced growth of GaNAs and InGaNAs using bismuth," $J$. Cryst. Growth, vol. 251, pp. 449-454, 2003

[28] T. Liu, S. Chandril, A. J. Ptak, D. Korakakis and T. H. Myers, "Bismuth surfactant effects for GaAsN and beryllium doping of GaAsN and GaInAsN grown by molecular beam epitaxy," J. Cryst. Growth, vol. 304, pp. 402-406, 2007

[29] E.C. Young, S. Tixier and T. Tiedje, "Bismuth surfactant growth of the dilute nitride $\mathrm{GaN}_{\mathrm{x}} \mathrm{As}_{1-\mathrm{x}}$, , J. Cryst Growth, vol. 279, pp. 316-320, 2005

[30] J. C. Harmand, G. Ungaro, L. Largeau and G. Le Roux, "Comparison of nitrogen incorporation in molecular-beam epitaxy of GaAsN, GaInAsN, and GaAsSbN," Appl. Phys. Lett., vol.77(16), pp. 2482-2484, Oct. 2000

[31] J. C. Harmand, A. Caliman, E. V. K. Rao, L. Largeau, J. Ramos, R. Teissier, L. Travers, G. Ungaro, B. Theys and I. F. L. Dias, "GaNAsSb: how does it compare with other dilute III-V-nitride alloys?," Semicond. Sci. Technol., vol.17, pp. 778-784, 2002

[32] V. P. Labella, M. R. Krause, Z. Ding and P. M. Thibado, "Arsenic-rich GaAs(001) surface structure," Surf. Sci. Reports vol.60, pp. 1-53, 2005
[33] S. Paul, J. B. Roy, and P. K. Basu, “ Empirical expressions for the alloy composition and temperature dependence of the band gap and intrinsic carrier density in $\mathrm{Ga}_{\mathrm{x}} \mathrm{In}_{1-\mathrm{x}} \mathrm{As}$," J. Appl. Phys., vol.69, pp. 827-829, 1991

[34] G. Moses and C. G. Van de Walle, "Band bowing and band alignment in InGaN alloys," Appl. Phys. Lett., vol.96, 021908, 2010

[35] A. de Bernabé, C. Prieto, L. González, Y. González and A. G. Every, "Elastic constants of InxGa1-xAs and InxGa1-xP determined using surface acoustic waves," J. Phys.: Condens. Matter, vol. 11, L323-L327, 1999

[36] I. Vurgaftman, J.R. Meyer and L.R. Ram-Mohan, "Band parameters for III-V compound semiconductors and their alloys," J. Appl. Phys., vol.89(11), pp. 5815-5875, 2001

[37] D. B. Jackrel et al., "Dilute nitride GaInNAs and GaInNAsSb solar cells by molecular beam epitaxy;" J. Appl. Phys., vol.101, 114916, Jun 2007

[38] N. Miyashita, Y. He, N. Ahsan and Y. Okada "Anneal mediated deeplevel dynamics in GaInNAsSb dilute nitrides lattice-matched to GaAs," $J$. Appl. Phys., vol.126, 143104, Oct 2019

[39] A. J. Ptak, D. J. Friedman, S. Kurtz and R. C. Reedy "Low-acceptorconcentration GaInNaAs grown by molecular-beam epitaxy for highcurrent p-i-n solar cell applications," J. Appl Phys., vol. 98, 094501, Nov 2005

[40] D. J. Friedman, J. F. Geisz, S. R. Kurtz and J. M. Olson "1-eV solar cells with GaInNAs active layer" J. Cryst Growth, vol. 195, pp. 409-415, 1998

[41] A. Aho, A. Tukiainen, V. Polojärvi and M. Guina "Performance assessment of multijunction solar cells incorporating GaInNAsSb," Nanoscale research letters, vol.9(1), pp. 1-7, Dec 2014 